\title{
Chapter 3 \\ Northern Neighbourhood: \\ Climate Change and Concern \\ for International Common Goods
}

\author{
Lisa Van Well, Johanna Roto and Julien Grunfelder
}

\begin{abstract}
Like the other chapters dedicated to one specific neighbourhood, this one begins by highlighting the demographic, economic and environmental stakes of the Northern neighbourhood. It raises the following questions: Whom does the Arctic region belong to? In other words, under what condition could the Arctic become an international common good, and what could the role of Europe be in this regard. Then it analyses the opportunities, risks and governance challenges connected to climate change. The chapter ends with strategic recommendations: as a difficulty emerges from the fact that the European part of the Northern neighbourhood belongs to various European territorial cooperation programmes, this calls for a more unified and ambitious EU strategy on this neighbourhood. Moreover, we emphasize that Russia is one of the key stakeholders in the Northern neighbourhood; in particular the Northern Dimension constitutes an important venue for a better dialogue with the Russian neighbour.
\end{abstract}

\subsection{Stakes}

In order to show the structures and dynamics of the Northern neighbourhood's space it is crucial to highlight its sparse settlement structure and long distances. Due to limited number of population in the Faroe Islands and Greenland (later referred to as "Westnorden") we use those at national level (Map 3.1).

\footnotetext{
L. Van Well · J. Roto $\cdot$ J. Grunfelder $(\bowtie)$

Nordregio, Stockholm, Sweden

e-mail: julien.grunfelder@nordregio.se

L. Van Well

e-mail: lisa.vanwell@ swedgeo.se

J. Roto

e-mail: johanna.roto@nordregio.se

(C) The Author(s) 2016

P. Beckouche et al. (eds.), Atlas of Challenges and Opportunities in European

Neighbourhoods, DOI 10.1007/978-3-319-28521-4_3
} 


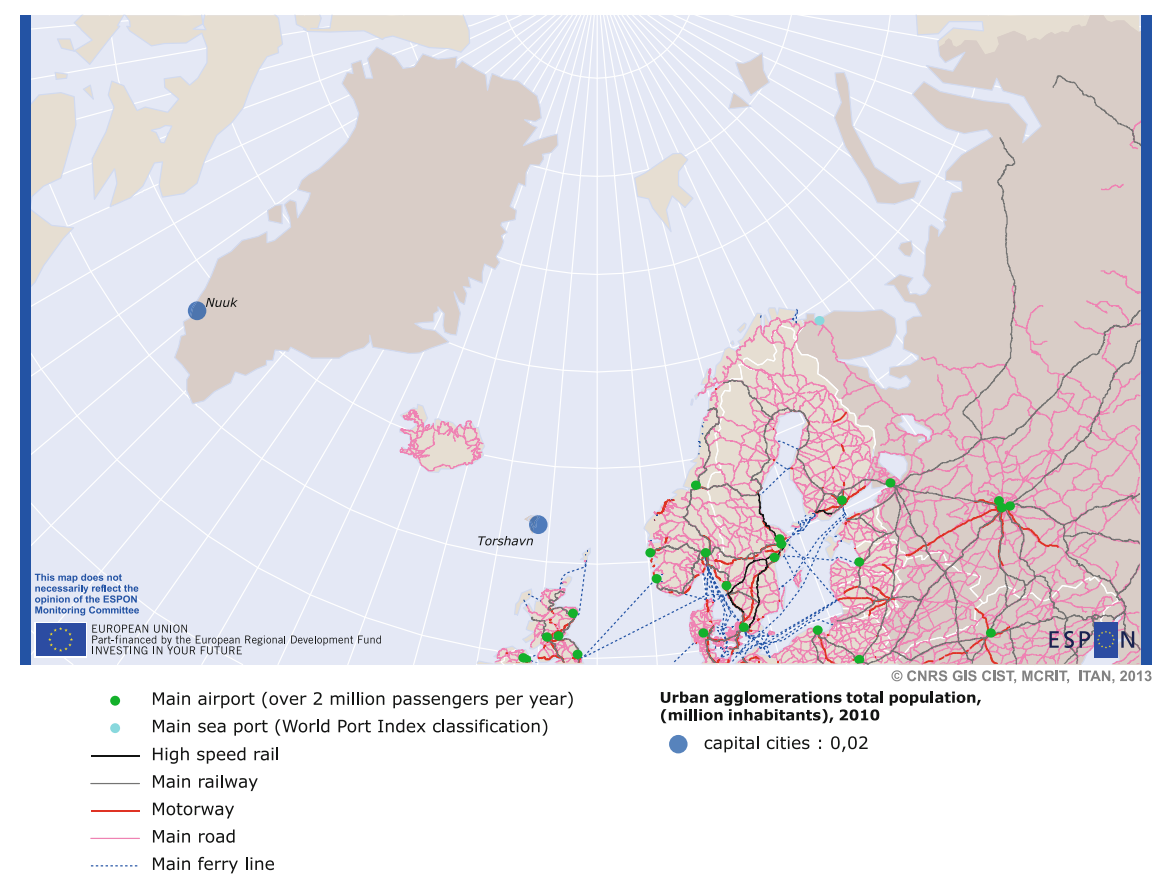

Map 3.1 Transport networks in the Northern neighbourhood (situation in 2010)

\subsubsection{Demographic}

Due to the extreme climate this neighbourhood is sparsely populated and has a small population size. Greenland and Nenets autonomous okrug (AO) in Russia have the smallest population in the neighbourhood (56,000 and 43,000 respectively). Densities are extremely low $\left(0.026 / \mathrm{km}^{2}\right.$ in Greenland and $0.24 / \mathrm{km}^{2}$ in Nenets AO). The most populated areas are Russian northern regions (Arkhangelskaya oblast). Several cities have more than 100,000 inhabitants in the Russian area. The largest cities with more than 200,000 inhabitants are Arkhangelsk, Murmansk, Petrozavodsk and Syktyvkar, which are the administrative centres and capital cities of oblast or Republic (Republic of Karelia and of Komi). More than $90 \%$ of the population of Greenland and Murmansk oblast live in urban centres; the share of urban population is also very high in other northern regions of Russia. Due to difficult climatic conditions, low accessibility and a limited access to services (e.g. health care and education), urban centres are becoming more attractive to live in.

The majority of the area has experienced a population decline over the last decade. In 2010, negative net migration was observed in the whole Russian part of the neighbourhood, except for Nenets AO (enormous development potential of the oil and gas extraction industry and increased investments in infrastructure development). Against the background of an overall drop in population, a slight population increase of $0.7-1.2 \%$ from 2002 to 2012 was observed in the Faroe Islands, 
as well as in Yamalo-Nenets and Nenets AO in Russia. Population growth in the Russian regions can be attributed to increasing oil and gas exploration here. In Nenets AO, oil and gas now constitutes $99 \%$ of all industrial activity; Yamalo-Nenets AO accounts for $90 \%$ of Russia's natural gas production.

Mobility is high. People are moving towards the regional centres and larger urban nodes within the area but also abroad, to the more populated areas in the West, East and South of the neighbourhood. A remarkable share of the migration is related to the limited labour possibilities in the home regions and in the case of more rural and peripheral regions, in relation to education possibilities. The fly in-fly out phenomenon is common in some settlements, especially in those where the economic structure is heavily concentrated on natural resource exploitation: when settlements do not otherwise offer sufficient quality to attract families to live locally, employees are flown to the work site where they work, usually long shifts for a number of continuous days and are then flown back to their home town for a number of days of rest.

\subsubsection{Socio-economic}

As to the gender balance of the population in the far North, the male population of working age is slightly predominant, particularly in Greenland and Murmansk oblast. This can be explained by development of strongly male-dominant industries: oil and gas exploration fields, mining activities, military bases, construction and forestry. Employment possibilities for females are quite limited and available mainly in larger urban centres.

When it comes to the total gender balance including all age groups, the proportion of females is significantly higher, except for Greenland. Adult males have higher death rates than females; this is exacerbated in the Northern neighbourhood due to tough work environment, harsh climate, low quality of housing, inconsistent and poor quality of health care and excessive consumption of alcohol among the male population (Socpol 2013). In the case of Greenland, the dominance of male population can be explained by high emigration of female population from the country.

Thus, life expectancy is not that high, especially for indigenous peoples. Life expectancy for women is only 71-75 years in Yamalo-Nenets AO, to be compared to $75-80$ in the Faroe Islands. The neighbourhood is characterized by a relatively high share of children, particularly in Greenland, Faroe Islands, and in Nenets AO (high birth rate among the indigenous population). As one might expect the share of elderly is low (6-12\% of the population) due to shorter life expectancy and out-migration of retired residents; for comparison, in the Eastern neighbourhood the respective indicator is above $12 \%$ in all areas except in the Caucuses.

GDP is the highest in Yamalo-Nenets AO, due to gas extraction activities. In GDP per capita, Nenets AO is dominant (the highest among all Russian regions, about 7-8 times above the country average), followed by Yamalo-Nenets AO (also narrowly specialized and based on exploitation of raw resources), Greenland and Faroe Islands. 


\subsubsection{Environmental}

The Arctic is under major environmental threat from a multitude of changes happening in the climate. Without major reductions in global carbon emissions, the Barents Sea will be completely ice free by 2050; this will have implications for the habitat and many other ice-associated organisms. The amount of annual average Arctic sea ice decreased over the period from 1979 to 2012 with a rate of more than $50 \%$ for summer perennial sea ice. The spatial extent has decreased in every season, and in every successive decade since 1979 (high confidence) (IPCC 2013). Map 3.2 shows the projected changes in 2090 based on Arctic climate impact assessment data from 2004; it shows the surface temperatures over land, the size of the polar ice cap, and the outer limits of permafrost.

There is an extraordinary increase in the sea surface temperature over the last three decades. The regional effects of climate change have already been observed in the region as the most severe effects of global warming have already been occurring

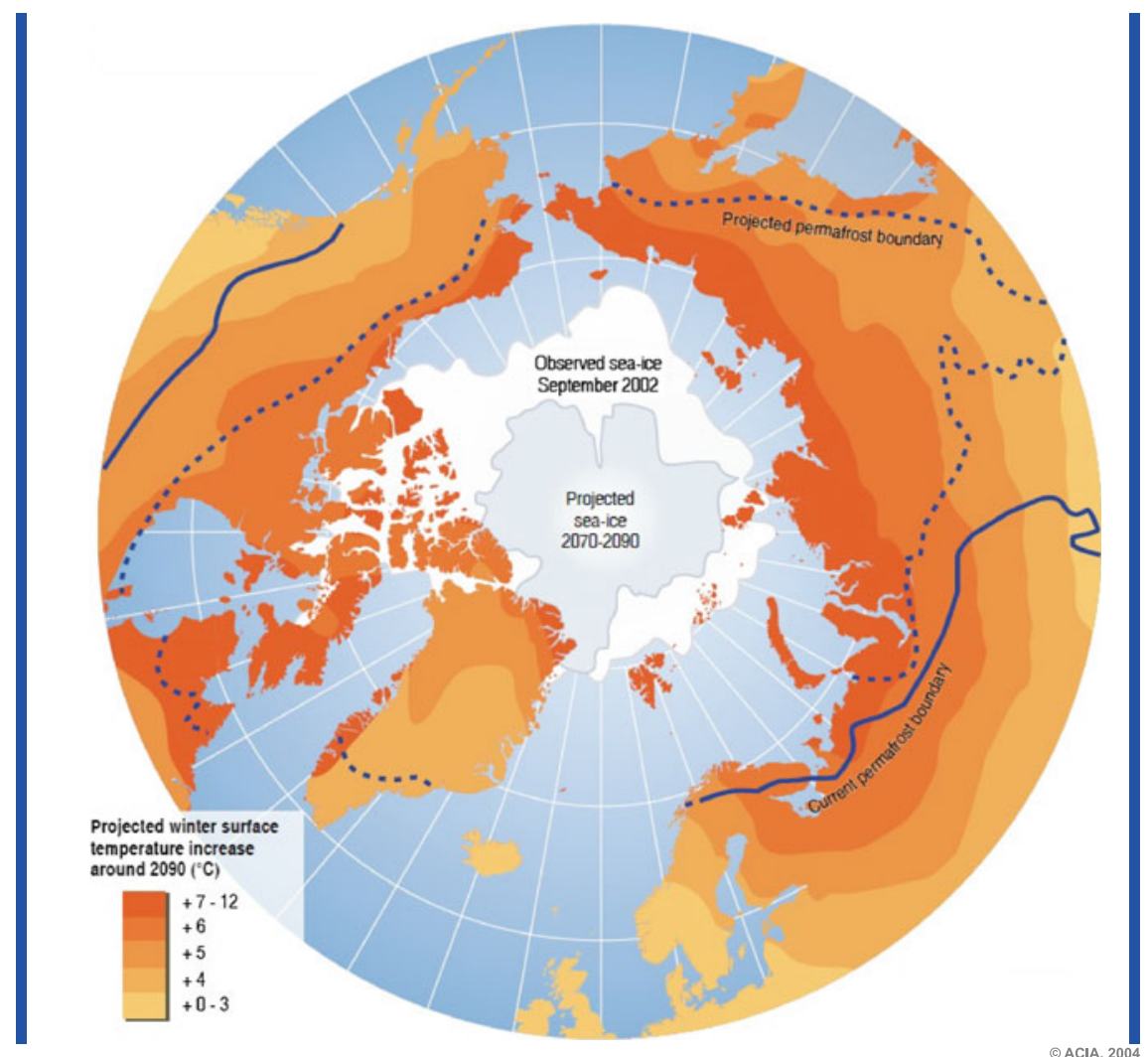

Map 3.2 Projected change in the Arctic climate. Source Protecting Arctic biodiversity, limitations and strengths of environmental agreements, GRID Arendal-A centre collaborating with UNEP 
faster in the Arctic than anywhere else on earth - almost twice the global average since 1980. IPCC predictions from 2013 indicate that the Arctic region will warm more rapidly than the global mean, and mean warming over land will be greater than over the ocean.

Early predicted models indicate that the Arctic will be ice-free during the summer by 2100; more recent studies predict that this will occur as early as 2035 (UNEP 2013). Hence, the region is extremely vulnerable to climate change. Arctic coastal communities and services are at risk of increasing threats of storms and shore erosion; almost all villages are already in search of relocation. Melting ground is putting transportation and the construction of infrastructure such as roads and buildings in danger. Thus far, melting of the Arctic ice cap has led to increased marine access and coastal wave action, changes in vegetation and fauna as well as changes in coastal ecology and biological diversity and production.

\subsection{The Arctic: A Remote but Increasingly Compelling Neighbourhood for the $\mathbf{E U}$}

\subsubsection{To Whom Does the Arctic Region Belong?}

The Arctic region is one of the few places on earth that has not yet been nationally defined so there is no uniform definition of the region. Several definitions exist from natural science, cultural and political boundaries perspectives. For instance there is a cultural definition of the Arctic that includes the areas inhabited by indigenous Arctic peoples and their traditional hunting grounds, beyond the Arctic Circle. The region is made up of Arctic Ocean sovereign states: United States, Canada, Greenland, Russia, Iceland, Sweden, Norway, and Finland, even though Finland, Iceland and Sweden have no territorial borders on the Arctic Ocean. On the other hand two of the Nordic countries, Denmark (via Greenland and Faroe Islands) and Norway (via Svalbard) together with the United States, Russia and Canada are considered as the Arctic Five.

Arctic resources were not clearly divided between countries at the outset. The Arctic catchment zone is now claimed by at least this Arctic five. The Arctic is very complex in terms of its geological structure and mostly uncharted. The Spitsbergen Treaty in 1920 acknowledged Norwegian sovereignty over Svalbard, but gave mineral rights to various countries. For instance, Russia and Norway today continue to mine and export coal in the region. China, Japan, South Korea and India have funded scientific missions in the region.

The international catchment zone (the Arctic seabed) is beyond the national jurisdiction limits and supposedly rich in minerals. The waters beyond the territorial waters of the coastal states are considered as international waters. Activities in international waters are expected to be carried out in the collective interests of all states, and benefits are expected to be shared equitably.

The seabed beyond the exclusive economic zones and confirmed extended continental shelf claims are considered to be the "heritage of all mankind" (Declaration of 
Principles Governing the Seabed - 1970 and Law of the Sea treaty) and administered by the UN International Seabed Authority. The Arctic is governed by international customary maritime law through the United Nations Convention on the Law of the Sea (UNCLOS), and cooperation is led by the Arctic Council, in addition to bilateral agreements between states with competing claims (Ebinger and Zambetakis 2009).

\subsubsection{Organisation of Space: The Key Role of Air Transport}

There are only a handful of big cities and towns where the majority of the Arctic population is concentrated. The settlements with a population above 50,000 inhabitants can be found in the Nordic countries, north-western Russia, Iceland and Alaska. In north-western Russia big urban centres emerged mainly due to development of resource extraction sector and to establishment of the North Sea Fleet in case of Murmansk (Megatrends 2011). About one third of the Arctic population lives in small and scattered settlements with a population of less than 5000 inhabitants; their livelihood is based on the utilisation of local natural resources (fisheries, forestry, hunting and gathering, herding). These communities are highly dispersed and comprise numerous cultural and ethnic groups (Rasmussen et al. 2013). Although the region has become more accessible due to development of modern transportation, infrastructure remains scattered across huge territories. Infrastructure development is, in many cases, linked to the distribution and access to natural resources and their value. The communities in the Arctic today are, to a large extent, dependent on air transport. Air routes mainly connect the peripheral areas with the largest urban centres, while accessibility to the small settlement remains extremely low. In this regard, smaller settlements have the worst access to necessary means and variety of services, including health care and education.

The region's economy is based on natural resources and their exploitation, which are not evenly spread across the region. In Nenets region, Labrador, Faroe Islands and Svalbard, the primary sectors account for about 20-40\% of employment. In terms of value, petroleum is the most important resource in the Arctic. Already in the beginning of the 2000s $16 \%$ of the world's petroleum and $25 \%$ of natural gas originated from the Arctic; $10 \%$ of world's wild fish was caught in the Arctic. Moreover, $10 \%$ of world's supply of nickel, cobalt, palladium, apatite and platinum comes from the Arctic. Among other resources in the region valuable for the worldwide markets are diamonds, gold and zinc. Besides minerals, oil and gas, the forestry sector provides a steady income and offers employment in these regions (Map 3.3).

The traditional economic activities, such as hunting, fisheries and herding still play important role for the northern communities in Iceland, Faroe Islands, Norway and Greenland. These renewable resources are mainly locally consumed (Rasmussen et al. 2013).

It is expected that most categories of tourism will flourish, particularly land-based tourism and large cruise shipping. An important favouring factor for the expansion of any economic activities is related to projected extension of the navigation season. 


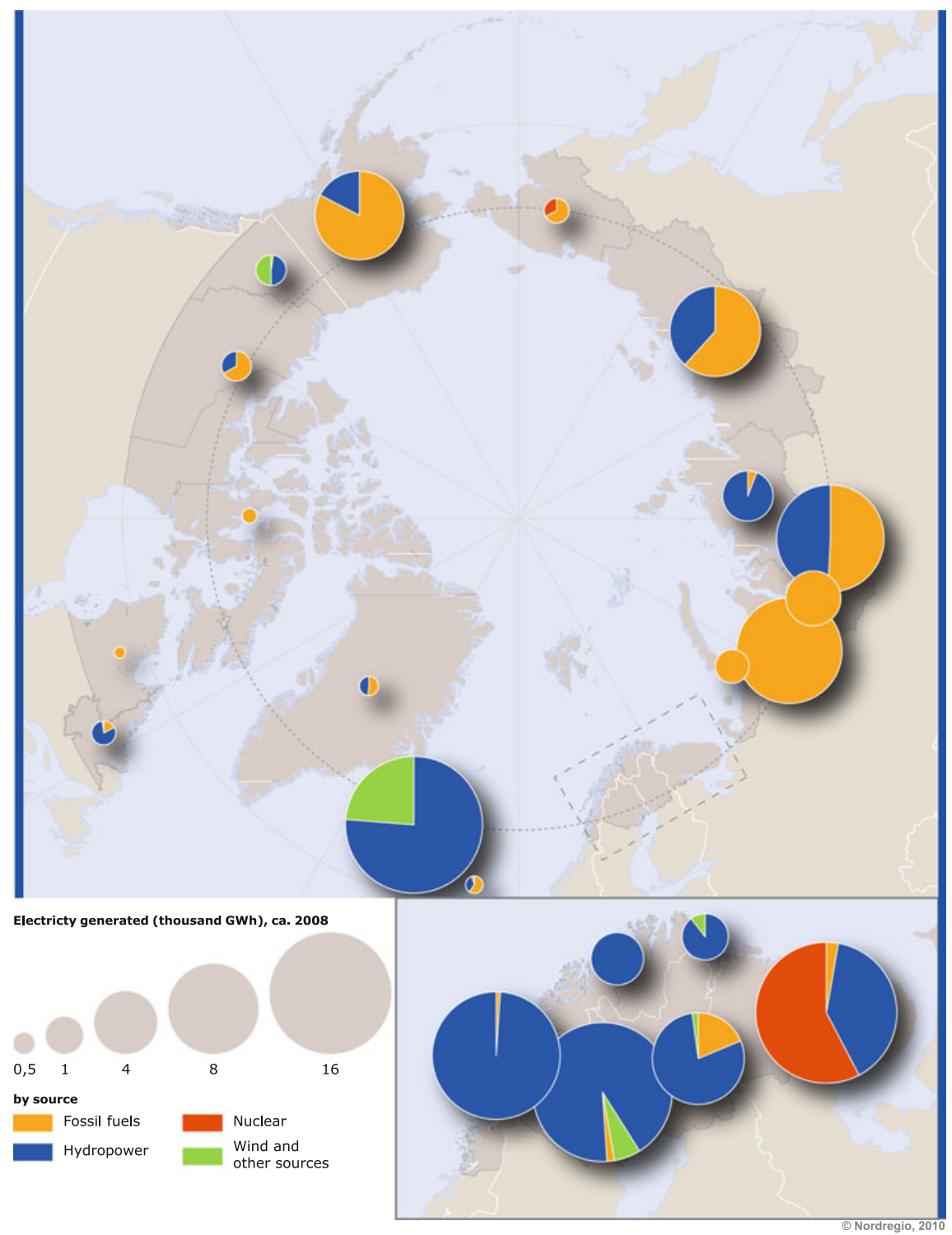

Map 3.3 Generation of electricity by main sources in the Arctic region

\subsubsection{The Impact of the Climate Change: Opportunities, Risks and Governance Challenges}

The impacts of climate change, thinning sea ice and melting permafrost have started to unsettle the geographies of Arctic governance and created a new agenda. These 
include management of the "new" environment, oil and gas exploration, trade, economic development, discussion of a legal framework, most importantly; governance and security. As the region undergoes a vast transformation, new states and political entities wish to become involved in the governance.

Due to increased accessibility of vast mineral, hydrocarbon and fishing resources, national security interests will be focusing on the future development of the region. The melting of the ice cap tends to initiate a number of scenarios all related to a potential conflict between the Arctic coastal states concerning maritime border disputes (Hong 2012). Furthermore, there is an emerging interest of non-Arctic states in shipping and polar research which is adding indefinite elements to the geopolitical development of the Arctic.

The potential hydrocarbon mine of the region holds a great potential for local communities in terms of economic benefit. While detailed information on Arctic petroleum resources still remains limited, the proportion of natural gas to oil in the region's hydrocarbon resources is three times more (US Geological Survey 2008). Besides hydrocarbon resources, when Arctic ice disappears, new shipping will reduce the maritime distances between the continents of Europe and Asia, providing strategic alternatives to other countries such as Japan, which would have an interest in Arctic access owing to its current dependence on shipping through the Strait of Malacca for most of its energy supplies.

Regarding security questions, the presence and role of the military will have to adapt to the new conditions; as the region becomes more accessible there will be more capacity for operations such as border patrolling, submarine activities, search and rescue. This will also require adaptation in terms of management of resources as monitoring of the waters will be of interest to the Arctic states. Since May 2011, all the member states of the Arctic Council have comprehensive Arctic strategies where they share some overall objectives. Different organisations and forums show consensus on the general need for international cooperation on Arctic affairs and for international governance of the Arctic. Nordic countries might have different views: while Norway has emphasized NATO's role, Finland, Denmark and Sweden consider the role of the EU as important. But they all place strong emphasis on the central role of the Arctic Council; with a wider mandate to new observers, the Council would be the natural place for such efforts.

Is the Council resistant enough to accommodate the on-going changes? In order to attract international investment for energy and mining projects, a clear legal framework will be needed as it would be central to the management of fisheries, oil and gas exploration as well as to national and energy security issues. It would also be central to the operation of commercial shipping and the management of possible accidents that may occur beyond national boundaries, along with any other potential activities that may arise. But the governance pattern is not easy to figure out; Asian powers, including China and Southern Korea, express a strong interest in being involved in Arctic governance. China gained observer state status at the Council meeting in Kiruna in 2013 and also has a station on Svalbard. Iceland is the first European country with whom China has a free trade agreement. 


\subsubsection{What Role for the EU?}

The region has the potential to strengthen international relations between America, Russia, Asia and the EU. The European Union has recently developed focus on an Arctic policy. Although the EU's territorial presence is limited and it does not have a shoreline on the Arctic Ocean, there are growing interactions between the Arctic region and the European territory. Three of the EU member states, Denmark (through Greenland), Finland and Sweden, have territories lying in the Arctic circle. Iceland and Norway are not members of the EU but they are members of the European Economic Area. In many international policy areas that are relevant for the Arctic, the EU holds shared competence with the member states and coordinates the positions of the member states in international negotiations. Therefore, the EU has influence on the socio-economic and environmental issues of the region, and has been engaged in the European Arctic cooperation since mid-1990s

The European Parliament has called for specific EU Arctic policies in order to increase the role that the EU can play in the region. Changing climate and economic forces are recognized as relevant factors behind the development of EU's policy interest (Koivurova et al. 2011). Greenland, a strategic area for future development, is of special importance for the EU. And Russia plays a key role for various initiatives especially in energy security matters in Europe. The EU recognizes the cooperation work carried out by the Arctic Council and it is committed to UNCLOS. In 2009, an application was submitted by the European Commission to become a permanent observer to the Arctic Council. However, the Council showed reluctance to the application questioning whether the EU has or should have any role.

\subsection{Strategic Synthesis: Importance of the Arctic, Common Goods Governance, Role of Russia}

It is crucial to support the socio-economic development of the Arctic communities in the phase of severe environmental changes, because, in the same time: (i) climate change should be dealt with immediately and on the long run, and (ii) it is important to pay special attention to the Northern communities as they face urgent development problems related to population decline, poor health status and migration. The guiding question is about retaining not only the economic, but also the social and environmental capital of the territory as nations compete for ownership of the natural resources. It is of utmost importance to ensure good governance under this high degree of uncertainty.

Since the large energy companies (with many being in state ownership), fishing interests, shipping companies as well as tourist business will grow, and with the opening of the Northwest Passage, commercial interests will increase dramatically. The complex interaction among all these actors will have a big impact on the 
geopolitics of the neighbourhood. Thus it is integral that all the actors consider the benefits for the entire Northern neighbourhood in a cooperative environment and not only their self-interest. It is of utmost importance that the notion of "common goods" be largely applied to this neighbourhood's resources, and paves the way for modern post-national governance.

In this more and more strategic neighbourhood, the notion of regionalisation (increasing flows and common stakes) might be an excellent driver for improved regionalism. As countries outside of the region are competing for access to a type of territorial capital that has traditionally been a common good rather than a strict jurisdictional territory, a neighbourhood's common legal framework will be needed, for instance, so as to attract international investment in a sustainable way and turn regional challenges into opportunities.

There are platforms on which cooperation on the Northern neighbourhood can develop, ranging from the interregional (e.g. the Barents cooperation) to the global (e.g. Arctic work in the International Maritime Organisation, IMO). The Arctic Council is so far the most important pan-Arctic forum. This is proven by the interests shown by the EU and China gain permanent observer status. However, since the decisions taken at the Council are not binding, it is up to discussion if the Council can play a direct role in Arctic governance in the future. On the other hand, the Council is well equipped to provide and build the knowledge that is important for facilitating multi-level cooperation on certain areas, especially security and rescue.

A difficulty emerges from the fact that the European part of the Northern neighbourhood belongs to various European territorial cooperation programmes: the Cross Border Cooperation (ENPI CBC) programme Kolarctic-Russia, the Northern Periphery and Arctic Programme 2014-2020 for the Westnorden, the Northern Dimension (a joint policy between the European Union, Russia, Norway and Iceland). Also the new self-government agreement in Greenland from 2009 may have some effects as Greenland took over i.e. responsibility for the mineral resource and in the existing EU-Greenland partnership Agreement the focus was changed from a fishery agreement to a partnership agreement with special focus on education. Lastly, countries of the region, including the EU countries, have either published their Arctic strategies during the last years or have a strategy that is under construction. This calls for a more unified and ambitious EU strategy on this neighbourhood.

It has to be emphasized that Russia is one of the key stakeholders in the Northern neighbourhood. Moreover, before the Ukrainian crisis there were negotiations on a New EU-Russia Agreement. The border agreement with Norway points to a direction that calls for stability and peaceful development in the region (e.g. the border delimitation agreement, dividing in fair terms, signed between Russia and Norway in the Barents and Polar Seas). This should be followed up as a good example for the future development of the region.

With regard to territorial institutional structures, the Northern Partnership is one of the primary initiatives in the area to address common challenges with regard to cross-border cooperation and external policies among the Nordic Countries, the 


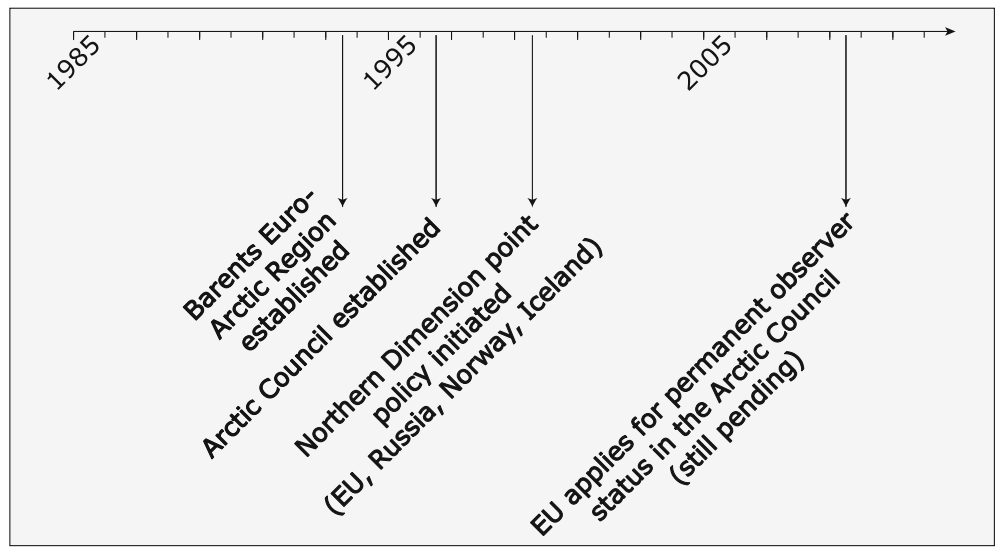

Fig. 3.1 Agreements with the EU—Northern neighbourhood

Baltic States and Russia - the Northern Dimension forms an important venue for dialogue with the Russian neighbour. The goal is to promote development and security in a number of areas-economic, social, environmental, judicial and regional development. Several different types of partnership agreements were created in the framework of the Northern Dimension: the NDEP (environmental issues), the NDPHS (public health and social wellbeing), the NDPC (culture) and the NDPTL (transport and logistics). The ND Institute (NDI) and ND Business Council (NDBC) were been created, along with an 'Arctic Window' to focus attention on the region (Fig. 3.1).

Open Access This chapter is distributed under the terms of the Creative Commons AttributionNoncommercial 2.5 License (http://creativecommons.org/licenses/by-nc/2.5/) which permits any noncommercial use, distribution, and reproduction in any medium, provided the original author(s) and source are credited. The images or other third party material in this chapter are included in the work's Creative Commons license, unless indicated otherwise in the credit line; if such material is not included in the work's Creative Commons license and the respective action is not permitted by statutory regulation, users will need to obtain permission from the license holder to duplicate, adapt or reproduce the material.

\section{References}

Ebinger, C., and E. Zambetakis. 2009. The geopolitics of Arctic melt. International Affairs 85(6): $1215-1232$.

Hong, N. 2012. The energy factor in the Arctic dispute: a pathway to conflict or cooperation? Journal of World Energy Law and Business 5(1):13-26, Oxford.

IPCC, 2013. Summary for Policymakers. In: Climate Change 2013: The Physical Science Basis. Contribution of Working Group I to the Fifth Assessment Report of the Intergovernmental 
Panel on Climate Change [Stocker, T.F., D. Qin, G.-K. Plattner, M. Tignor, S. K. Allen, J. Boschung, A. Nauels, Y. Xia, V. Bex and P.M. Midgley (eds.)]. Cambridge University Press, Cambridge, United Kingdom and New York, NY, USA.

Koivurova, T., et al. 2011. The present and future competence of the European Union in the Arctic. Polar record 48(4): 361-371.

Mega Trends. 2011. Nordic Council of Ministers. TemaNord 2011:527. Available at: http://www. nordregio.se/Publications/Publications-2011/Megatrends/. Accessed 6 Nov 2013.

Rasmussen, R.O., G. Hovelsrud, S. Gearheard. 2013. AHDR-II draft community viability and adaptation.

Socpol. 2013. Social atlas of Russian regions. Independent Institute for Social Policy.

UNEP. 2013. New awareness of and opportunities for UNEP to address climate change in the Arctic. A background paper for the Arctic side event at the Governing Council/Global Environmental Ministerial Forum, What Future for the Arctic? February 18, Nairobi.

US Geological Survey. 2008. Assessment of undiscovered oil and gas in the Arctic. US Geological Survey Fact Sheet 2008. 